\title{
IDENTIFIKASI BAKTERI ASAM LAKTAT DARI HASIL FERMENTASI SELADA ROMAIN (Lactuca sativa var. longifolia Lam.) MENGGUNAKAN GEN 16S rRNA
}

\author{
Maria A. Gani ${ }^{1)}$, Trina E. Tallei ${ }^{2)}$, Fatimawali ${ }^{1)}$ \\ ${ }^{1)}$ Program Studi Farmasi FMIPA UNSRAT Manado, 95115 \\ 2) Jurusan Biologi Farmasi FMIPA UNSRAT Manado, 95115
}

\begin{abstract}
Lactic acid bacteria (LAB) is a group of bacteria that produce lactic acid as the major metabolic end product of carbohydrate fermentation. LAB are highly beneficial because of their probiotic potential properties and as functional starter cultures in food fermentation. This study was aimed to identify the LAB species isolated from romaine lettuce fermented product by using molecular identification method with $16 S$ rRNA gene marker. The fermented product was diluted and spread onto MRS agar supplemented with $1 \%$ of $\mathrm{CaCO}_{3}$ and then purified by using streak method. Both isolates were positive Gram bacteria and gave negative results from catalase test. The result of molecular identification showed that LAB from romaine lettuce fermented product have each 99 and $100 \%$ similarity to Enterococcus faecium that known have properties as probiotic potential and functional culture starter.
\end{abstract}

Key words: lactic acid bacteria, fermentation, probiotic, Enterococcus faecium, Lactuca sativa var. Longifolia Lam.

\begin{abstract}
ABSTRAK
Bakteri asam laktat (BAL) merupakan bakteri yang menghasilkan asam laktat sebagai metabolit utamanya dalam fermentasi karbohidrat. BAL merupakan bakteri yang menguntungkan karena memiliki aktivitas probiotik potensial dan dapat berguna sebagai starter dalam proses fermentasi makanan. Penelitian ini bertujuan untuk mengidentifikasi spesies BAL yang diisolasi dari hasil fermentasi selada romain menggunakan metode identifikasi molekuler dengan gen penanda $16 \mathrm{~S}$ rRNA. Cairan hasil fermentasi diencerkan dan ditebar pada media MRS agar yang telah dicampur dengan $\mathrm{CaCO}_{3} 1 \%$ dan kemudian dimurnikan menggunakan metode streak plate. Kedua isolat merupakan bakteri Gram positif dan menunjukkan hasil negatif pada uji katalase. Hasil identifikasi molekuler menunjukkan bahwa kedua BAL hasil fermentasi selada romain memiliki kemiripan masing-masing 99 dan $100 \%$ dengan Enterococcus faecium yang diketahui memiliki aktivitas probiotik.
\end{abstract}

Kata Kunci: bakteri asam laktat, fermentasi, probiotik, Enterococcus faecium, Lactuca sativa var. longifolia Lam. 


\section{PENDAHULUAN}

Bakteri asam laktat (BAL) merupakan bakteri yang menghasilkan asam laktat sebagai metabolit utamanya. BAL merupakan bakteri yang menguntungkan karena terbukti dapat menghambat pertumbuhan bakteri patogen seperti Escherichia coli serta jamur seperti Aspergillus fumigatus (Dow et al., 2010; Lahtinen et al., 2012).

Bakteri asam laktat dapat ditemukan dalam makanan fermentasi (Lahtinen et al., 2012). Fermentasi merupakan teknik yang digunakan untuk mengawetkan suatu makanan (Fleck et al., 2012).

Bakteri asam laktat telah diteliti dapat memberikan manfaat baik bagi kesehatan yang membuatnya disebut sebagai probiotik potensial. Keuntungan mengomsumsi probiotik antara lain; dapat meningkatkan kekebalan tubuh untuk melawan infeksi, menekan bakteri patogen dan menyeimbangkan kondisi mikrobiota di usus serta menurunkan serum kolesterol, (Kaur et al., 2014; Lahtinen et al., 2012).

Sampai saat ini BAL telah banyak diidentifikasi berdasarkan karakterisitik fenotipnya, namun identifikasi ini tidak sepenuhnya akurat serta membutuhkan waktu yang relatif lama (Khalid, 2011). Maka dari itu, saat ini identifikasi BAL telah beralih ke arah molekuler, salah satunya menggunakan gen $16 \mathrm{~S}$ rRNA (Khalid, 2011).

Gen 16S rRNA merupakan gen yang terletak pada ribosom sub unit kecil dan memiliki sekitar 1500 pasang basa yang dapat digunakan untuk identifikasi suatu bakteri (Das et al., 2014; Senthilraj et al., 2016).

\section{METODE PENELITIAN}

\section{Tempat dan Waktu Penelitian}

Penelitian telah dilakukan di Laboratorium Mikrobiologi Program Studi Farmasi, Laboratorium Mikrobiologi dan Laboratorium Bioteknologi Jurusan Biologi Fakultas Matematika dan Ilmu Pengetahuan Alam Universitas Sam Ratulangi. Penelitian ini terlaksana pada bulan Oktober 2018 - November 2018.

\section{Alat dan Bahan}

Alat yang digunakan antara lain; alat ekstraksi DNA (Presto ${ }^{\mathrm{TM}}$ Mini gDNA Bacteria), alat PCR (TOYOBO KOD FX Neo Catalog No. KFX-201) alat elektroforesis dan alat purifikasi gel DNA (Zymoclean $^{\mathrm{TM}}$ Gel DNA Recovery).

Bahan yang digunakan antara lain; selada romain, MRS (de Man, Rogosa and Sharpe) agar, Geneaid Presto ${ }^{\mathrm{TM}}$ Mini gDNA Bacteria Kit (GBB100), Zymoclean $^{\mathrm{TM}}$ Gel DNA Recovery Kit (Zymo Research), PCR Buffer KOD FX neo, dNTPs, Primer 27F, Primer 1492R, KOD FX Neo, bubuk agarose, buffer TBE (Tris-Boric EDTA) 1X, DNA ladder, bakteri Escherichia coli (Migula) Castellani and Chalmers (ATCC $\left.{ }^{\circledR} 25922\right)$.

\section{Cara Kerja}

\section{Fermentasi}

Daun selada romain dimasukkan ke dalam wadah fermentasi, diberi pemberat dan ditambahkan larutan garam $10 \%$. Proses fermentasi dilakukan pada suhu ruang selama 4 hari tanpa cahaya di dalam wadah fermentasi yang ditutup rapat.

\section{Isolasi Bakteri}

Sebanyak $100 \mu \mathrm{L}$ cairan hasil fermentasi dipipet dan diencerkan dengan pengenceran berseri sampai $10^{-5}$. Setelah itu cairan hasil fermentasi yang telah diencerkan ditebar pada media MRS agar 
yang mengandung $\mathrm{CaCO}_{3}$ dan diinkubasi selama 48 jam pada suhu $37^{\circ} \mathrm{C}$ (Lawalata et al., 2011). Setelah bakteri tumbuh, masing-masing koloni dengan zona bening disekitarnya dimurnikan pada MRS agar yang baru menggunakan metode streak plate.

\section{Pewarnaan Gram}

Satu Ose bakteri diambil dan digoreskan pada kaca preparat, ditetesi akuades dan difiksasi di atas pembakar Bunsen dan kemudian diwarnai menggunakan metode (Reynolds, 2011).

\section{Uji Katalase}

Masing-masing isolat dan bakteri pembanding (E. Coli) yang telah dibiakkan diambil terlebih dahulu menggunakan jarum Ose dan diletakkan di kaca preparat yang sama. Setelah itu ditetesi 2 tetes larutan $\mathrm{H}_{2} \mathrm{O}_{2} \quad 5 \%$ lalu diamati dan dibandingkan reaksi pada isolat dengan bakteri pembanding (Tallei, komunikasi pribadi).

\section{Ekstraksi DNA}

Ekstraksi DNA dilakukan menggunakan kit Presto $^{\mathrm{TM}}$ Mini gDNA Bacteria.

\section{Amplifikasi DNA}

Fragmen DNA diamplifikasi menggunakan kit PCR KOD FX Neo Catalog No. KFX-201 (Toyobo). Komponen master mix PCR yaitu; $5 \mu \mathrm{l}$ $\mathrm{ddH}_{2} \mathrm{O}, 12.5 \mu \mathrm{l}$ PCR Buffer KOD FX neo, $5 \mu \mathrm{l}$ dNTPs, $0.5 \mu \mathrm{l}$ KOD FX Neo, $1 \mu \mathrm{l}$ DNA template, $0.5 \mu \mathrm{l}$ primer $27 \mathrm{~F}$ (forward) dan $0.5 \mu \mathrm{l}$ primer 1492R (reverse). Tahap pertama yaitu denaturasi awal pada suhu $95^{\circ} \mathrm{C}$ selama 3 menit (1 siklus). Tahap kedua yaitu denaturasi pada suhu $98^{\circ} \mathrm{C}$ selama 15 detik, penempelan primer pada suhu $52^{\circ} \mathrm{C}$ selama 30 detik dan elongasi pada suhu $68^{\circ} \mathrm{C}$ selama 45 detik. Tahap kedua dilakukan sebanyak 35 siklus. Tahap terakhir yaitu holding dilakukan pada suhu $4^{\circ} \mathrm{C}$ (Genetika Science Indonesia, komunikasi pribadi).

\section{Elektroforesis}

Sebanyak $5 \quad \mu \mathrm{l}$ DNA ladder dimasukan ke dalam gel agarosa $1 \%$ untuk menghasilkan ukuran pita DNA. Selanjutnya produk PCR yang mengandung loading dye dimasukkan ke dalam sumur-sumur gel agarosa lalu dialirkan listrik dengan tegangan 100 Volt selama 30 menit. Fragmen DNA divisualisasi menggunakan $U V$ transluminator dan didokumentasi menggunakan kamera digital (Genetika Science Indonesia, komunikasi pribadi).

\section{Purifikasi Gel DNA}

Gel DNA hasil elektroforesis dipurifikasi menggunakan kit Zymoclean $^{\mathrm{TM}}$ Gel DNA Recovery.

\section{Sekuensing}

Fragmen DNA yang telah diamplifikasi beserta dengan primernya dikirim ke 1Base C.O Malaysia untuk dilakukan proses sekuensing. Sekuensing dilakukan untuk menentukan urutan fragmen DNA.

\section{Analisis Data}

Kromatogram

disunting menggunakan Geneious 11.1.5. Sebanyak 50 nukleotida di bagian awal dan akhir dari sekuens yang mengandung primer dihilangkan. Konsensus sekuens diperoleh dengan cara pairwise alignment dari sekuens forward dan reverse. Setelah itu sekuens DNA dianalisis menggunakan Basic Local Alignment Search Tool (BLAST) untuk mencari sekuens yang serupa yang tersedia di GenBank. Kemudian Sekuens 16S rRNA dijajarkan menggunakan Multalin 5.4.1 (Tallei dan Kolondam, 2015). Setelah itu, pohon filogenetik dibuat menggunakan piranti 
MEGA 7.0.26 dengan metode UPGMA. Jarak genetik diperoleh berdasarkan Kimura-2 parameter method yang terintegrasi pada MEGA 7.0.26 (Linelejan, 2018; Rambitan, 2018).

\section{HASIL DAN PEMBAHASAN}

\section{Isolasi Bakteri Asam Laktat}

Hasil fermentasi merupakan sumber isolat bakteri asam laktat (BAL). Cairan hasil fermentasi selama 4 hari pada suhu ruang dan dalam keadaan gelap ditebar di media MRS agar yang mengandung $\mathrm{CaCO}_{3} 1 \%$ dan diinkubasi. Hasil inkubasi menunjukkan adanya pertumbuhan koloni bakteri, sehingga dapat dinyatakan bahwa bakteri yang tumbuh merupakan bakteri yang tahan terhadap konsentrasi garam $10 \%$, sesuai dengan karakteristik BAL (Gomes et al., 2010). Koloni bakteri yang tumbuh terlihat memiliki zona bening di sekitarnya. Zona bening ini yaitu endapan kalsium laktat yang merupakan produk dari reaksi antara asam laktat yang diproduksi oleh bakteri dengan $\mathrm{CaCO}_{3} 1 \%$ yang ada pada media.

Terdapat perbedaan jumlah koloni yang tumbuh pada setiap pengenceran. Pada pengenceran $10^{-5}$ terdapat 5 koloni bakteri, pada pengenceran $10^{-4}$ terdapat 26 koloni bakteri sedangkan pada pengenceran $10^{-3}, 10^{-2}, 10^{-1}$ serta cairan fermentasi tanpa pengenceran koloni bakteri tidak dapat dihitung. Sehingga dapat dinyatakan bahwa semakin banyak pengenceran yang dilakukan maka jumlah koloni bakteri akan semakin berkurang.

Dari pengenceran $10^{-4}$ dan $10^{-5}$ diperoleh dua koloni dengan morfologi yang berbeda serta memiliki zona bening di sekitarnya. Koloni-koloni ini dimurnikan menggunakan metode streak plate sehingga didapat 2 isolat murni yang diberi nama MG1 dan MG2. MG1 memiliki warna putih susu, tepian yang tidak beraturan, berbentuk bulat, berukuran kecil dan berelevasi cembung. MG2 memiliki warna putih, tepian rata, berbentuk bulat, berukuran sedang dan berelevasi cembung.

\section{Pewarnaan Gram}

Hasil pewarnaan Gram menunjukkan bahwa kedua isolat baik MG1 maupun MG2 berwarna ungu, sehingga dapat dinyatakan bahwa kedua isolat merupakan bakteri Gram positif . Hasil pengamatan di bawah mikroskop dengan perbesaran 100 kali menunjukkan bahwa isolat MG1 maupun MG2 memiliki bentuk sel kokus. Berdasarkan hal tersebut maka dapat dinyatakan isolat MG1 dan MG2 memiliki karakteristik bakteri asam laktat (BAL) yang mana menurut Lahtinen et al. (2012) BAL merupakan bakteri Gram positif yang berbentuk batang atau kokus.

\section{Uji Katalase}

Hasil uji katalase menunjukkan bahwa kedua isolat baik MG1 maupun MG2 memiliki katalase negatif. Hal ini dikarenakan kedua isolat tidak menghasilkan gelembung ketika ditetesi larutan $\mathrm{H}_{2} \mathrm{O}_{2} 5 \%$. Hasil ini dibandingkan dengan bakteri pembanding (Escherichia coli) yang diketahui memiliki katalase positif serta menghasilkan gelembung ketika ditetesi dengan larutan $\mathrm{H}_{2} \mathrm{O}_{2} 5 \%$. Ini menandakan bahwa kedua isolat tidak menghasilkan enzim katalase yang dapat mengkatalisis $\mathrm{H}_{2} \mathrm{O}_{2}$ menjadi $2 \mathrm{H}_{2} \mathrm{O}$ dan $\mathrm{O}_{2}$, dimana $\mathrm{O}_{2}$ merupakan gelembung yang terlihat pada pengujian katalase dari $E$. coli.

\section{Identifikasi Molekuler Menggunakan Gen 16S rRNA}




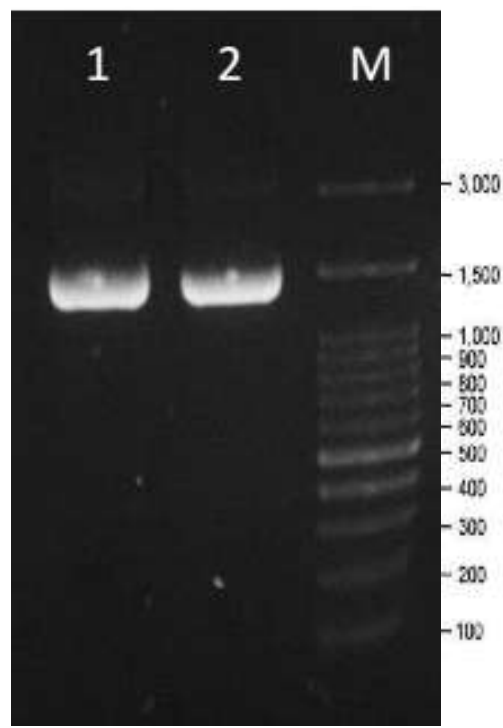

Gambar 1. Hasil elektroforesis

Berdasarkan hasil elektroforesis (Gambar 1) dapat diketahui bahwa fragmen DNA yang diamplifikasi memiliki panjang sekitar $1400 \mathrm{bp}$. Setelah dilihat menggunakan Geneious 11.1.5, diketahui bahwa MG1 memiliki panjang 1400 bp sedangkan MG2 memiliki panjang 1411 bp. Fragmen DNA ini merupakan daerah yang mengkode $16 \mathrm{~S}$ rRNA. Fragmen ini memiliki daerah variabel, dimana pada daerah ini urutan basa nitrogen pada setiap spesies bakteri berbeda-beda sehingga dapat menentukan spesies dari MG1 dan MG2.

Hasil identifikasi menunjukkan bahwa MG1 memiliki kemiripan 99\% dan MG2 memiliki kemiripan 100\% dengan kebanyakan spesies Enterococcus faecium yang diteliti, kecuali E. faecium strain JE1. Hal ini menyatakan bahwa kedua isolat merupakan spesies yang sama meskipun memperlihatkan morfologi yang berbeda. Hal ini dikarenakan karakteristik morfologi yang ditunjukkan oleh MG1 maupun MG2 sangat dipengaruhi oleh kondisi lingkungan, seperti suhu dan $\mathrm{pH}$, sehingga identifikasi berdasarkan karakteristik morfologinya saja bisa tidak akurat.

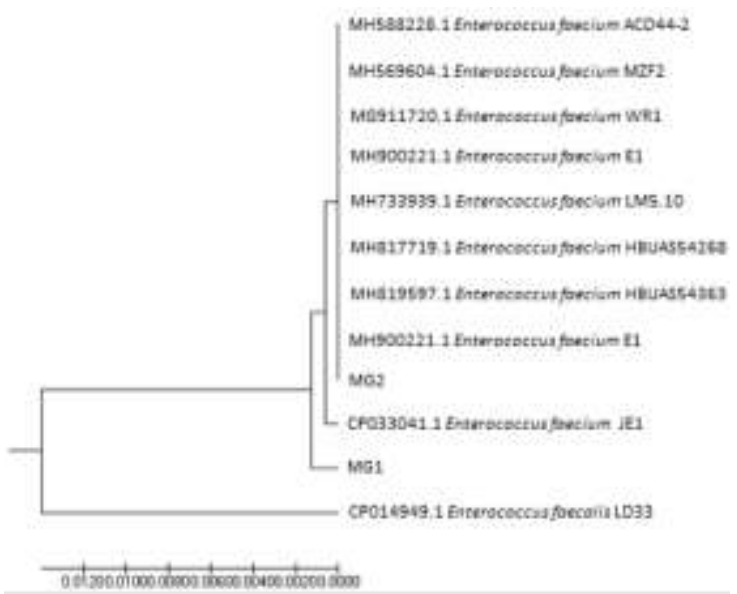

Gambar 2. Rekonstruksi filogenetik

Hasil rekonstruksi pohon filogenetik dapat dilihat pada Gambar 2, dimana isolat MG1 dan MG2 berada dalam spesies yang sama dengan Enterococcus faecium, dibandingkan dengan pembandingnya yaitu $E$. faecalis. Jarak genetik antar taksa dihitung menggunakan metode Kimura 2parameter (Tabel 1) (Kimura, 1980). Jarak genetik antara isolat MG1 dengan MG2 dan E. faecium lainnya yaitu $0.002(0.2 \%)$, kecuali strain JEI yaitu $0,004(0,4 \%)$. Jarak genetik antara MG2 dengan $E$. faecium lainnya yaitu 0.000 , kecuali dengan strain JEI yaitu $0,001(0,1 \%)$. Menurut Konstantinidis dan Tiedje (2005), berdasarkan identitas sekuens gen 16S rRNA, bakteri dapat dinyatakan spesies yang sama apabila kemiripannya lebih besar dari 97\%. Meskipun demikian, Edgar (2018) menyatakan bahwa ambang identitas optimal spesies bakteri yaitu $\sim 99 \%$ untuk sekuens 16S rRNA utuh, dan $\sim 100 \%$ untuk daerah V4 yang hypervariable. 
Tabel 1. Jarak genetic antar taksa menggunakan metode Kimura 2 parameter

\begin{tabular}{|c|c|c|c|c|c|c|c|c|c|c|c|c|c|}
\hline No. & Strain & 1 & 2 & 3 & 4 & 5 & 6 & 7 & 8 & 9 & 10 & 11 & 12 \\
\hline 1 & MG1 & & & & & & & & & & & & \\
\hline 2 & MG2 & 0,002 & & & & & & & & & & & \\
\hline 3 & CP033041.1 E. faecium JE1 & 0,004 & 0,001 & & & & & & & & & & \\
\hline 4 & MH900221.1 E. faecium E1 & 0,002 & 0,000 & 0,001 & & & & & & & & & \\
\hline 5 & MH819597.1 E. faecium HBUAS54363 & 0,002 & 0,000 & 0,001 & 0,000 & & & & & & & & \\
\hline 6 & MH817719.1 E. faecium HBUAS54268 & 0,002 & 0,000 & 0,001 & 0,000 & 0,000 & & & & & & & \\
\hline 7 & MH733939.1 E. faecium LM5.10 & 0,002 & 0,000 & 0,001 & 0,000 & 0,000 & 0,000 & & & & & & \\
\hline 8 & MG976843.1 E. faecium E6 & 0,002 & 0,000 & 0,001 & 0,000 & 0,000 & 0,000 & 0,000 & & & & & \\
\hline 9 & MG911720.1 E. faecium WR1 & 0,002 & 0,000 & 0,001 & 0,000 & 0,000 & 0,000 & 0,000 & 0,000 & & & & \\
\hline 10 & MH588228.1 E. faecium ACD44-2 & 0,002 & 0,000 & 0,001 & 0,000 & 0,000 & 0,000 & 0,000 & 0,000 & 0,000 & & & \\
\hline 11 & MH569604.1 E. faecium MZF2 & 0,002 & 0,000 & 0,001 & 0,000 & 0,000 & 0,000 & 0,000 & 0,000 & 0,000 & 0,000 & & \\
\hline 12 & CP014949.1 E. faecalis LD33 & 0,030 & 0,028 & 0,028 & 0,028 & 0,028 & 0,028 & 0,028 & 0,028 & 0,028 & 0,028 & 0,028 & \\
\hline
\end{tabular}

Genus Enterococcus termasuk ke dalam bakteri penghasil asam laktat dengan ciri-ciri Gram positif, katalase negatif, tidak membentuk spora, fakultatif anaerob serta berbentuk kokus. Secara filogenetik, Enterococcus termasuk ke dalam filum Firmicutes, kelas Bacilli, ordo Lactobacillales dan famili Enterococcacae (Gomes et al., 2010; Lahtinen et al., 2012).

Enterococcus faecium memiliki banyak manfaat menguntungkan bagi kesehatan, antara lain; dapat mengasimilasi kolestrol (El-Jeni et al., 2015), dapat menurunkan angka kejadian diare (Jatkauskas dan Vrotniakienè, 2014), dapat meningkatkan sistem imun (Scharek et al., 2005), dapat meningkatkan berat badan (Simonova et al., 2009) serta memiliki aktivitas antibakteri dari bermacam-macam bakteriosin yang diproduksinya (Cintas et al., 1997; El-Jeni et al., 2015)

Enterococcus faecium dapat dijadikan starter dalam proses fermentasi makanan (Gomes et al., 2010) yang membuatnya dapat mencegah kontaminasi dari makanan yang difermentasi. Selain itu, asam laktat yang diproduksinya dapat memberikan cita rasa unik pada makanan yang membuatnya disukai banyak orang (Lahtinen et al., 2012).

\section{KESIMPULAN}

Berdasarkan penelitian yang telah dilakukan, maka dapat disimpulkan bahwa isolat bakteri asam laktat MG1 dan MG2 hasil fermentasi selada romain merupakan Enterococcus faecium.

\section{SARAN}

Perlu diadakan penelitian lebih lanjut tentang probiotik potensial yang mencakup aktivitas antibakteri, enzim BSH (bile salt hydrolase) dan kemampuan tahan asam dari Enterococcus faecium.

\section{DAFTAR PUSTAKA}

Cintas L. M., Casaus, P., Håvarstein, L. S., Hernández, P. E., Nes I. F.

1997. Biochemical and genetic characterization of enterocin $\mathrm{P}$, a novel sec-dependent bacteriocin from Enterococcus faecium P13 with a broad antimicrobial spectrum. Appl Environ Microbiol. 63(11): 4321-4330.

Das, S., Dash, H. R., Mangwani, N., Chakraborty, J., Kumari, S. 2014. Understanding Molecular Identification and Polyphasic Taxonomic Approaches for Genetic Relatedness and Phylogenetic Relationships of Microorganisms. Journal of Microbiological Methods. 103: 84.

Dow. A., C. Alvarado., M. Brashears. 2010. Reduction of inoculated Salmonella cocktail in ground 
turkey and turkey breasts using Lactobacillus-based intervention. Poultry Science. 90: 876.

Edgar, R. C. 2018. Updating the 97\% Identity Threshold for $16 \mathrm{~S}$ Ribosomal RNA OTUs. Bioinformatics. 34(14): 2371-2375.

El-Jeni, R., El Bour, M., Calo-Mata, P., Bohme, K., Fernandez-No, I. C., Barros-Velazquez, J., BouhaoualaZahar, B. 2015. In-vitro probiotic profiling of novel Enterococcus faecium and Leuconostoc mesenteroides Lactic Acid Bacteria strains from Tunisian freshwater fishes. Canadian Journal of Microbiology. 62(1): 60-71.

Fleck. C. Z., Savić, V., Kozačinski, L., Njari, B., Zdolec, N., Filipović, I. 2012. Identification of lactic acid bacteria isolated from dry fermented sausages.Veterinarski Arhiv. 82(3): 265.

Gomes, B. C., Franco, B. D. G. M., Martinis, E. C. P. D. 2010. Dualistic aspects of Enterococcus spp. in foods. A. Mandez-Vilaz. 1119-1122.

Jatkauskas, J., dan V. Vrotniakienè. 2014. Effect of Encapsulated Probiotic Enterococcus faecium Strain on Diarrhoea Patterns and Performance of Early Weaned Calves. Vet Med Zoot. 67(89): 47.

Khalid. K. 2011. An Oerview of Lactic Acid Bacteria. International Journal of Biosciences. 1(3): 2.

Kimura, M. 1980. A simple method for estimating evolutionary rate of base substitutions through comparative studies of nucleotide sequences.
Journal of Molecular Evolution.

16: 111-120.

Konstantinidis, K. T. dan Tiedje J. M. 2005. Genomic Insights that advance the species definition for prokaryotes. Proc. Natl. Acad. Sci. USA. 102(7): 2567- 2572.

Lahtinen, S., Ouwehand, A. C., Salminen, S., Wright, A. V. 2012. Lactic Acid Bacteria Microbiological and Functional Aspects. Edisi keempat. CRC Press, London.

Lawalata, H.J., Sembiring, L., Rahayu, E. S. 2011. Molecular identification of Lactic Acid Bacteria producing antimicrobial agents from bakasang, an Indonesian traditional fermented fish product. Indonesian J. Biotech. 16(2): 93-99.

Linelejan, Y. T., Umboh, S. D., Tallei, T. E. 2018. Identifikasi Bakteri Endofit Daun Ficus Minahassae (Teijsm. \& De Vriese) Miq. Berdasarkan Gen 16s rRNA. Jurnal MIPA UNSRAT. 7(2): 17.

Meremae, K., Elias, P., Tamme, P. T., Kramarenko, T., Lillenberg, M., Karus, A., Hanninen, M. L., Roasto, M. 2010. The occurrence of Campylobacter spp. in Estonian broiler chicken production in 2002- 2007. Food Control. 21: 272- 275.

Rambitan, G. 2017. Isolasi dan Identifikasi Bakteri Asam Laktat Hasil Fermentasi Kol Merah (Brassica oleracea L.) sebagai probiotik potensial [skripsi]. FMIPA UNSRAT, Manado. 
Reynolds, J. 2011. The Gram Strain. Richard Collage, Bournemounth.

Scharek, L., Guth, J., Reiter, K., Weyrauch, D. K., Taras, D., Schwerk, P., Schierack, M. F., Schmidt, L., Wieler, H., Tedin, K. 2005. Influence of a probiotic Enterococcus faecium strain on development of the immune system of sows and piglets. Vet. Immunol. Immunopathol. 105: 151- 161.

Senthilraj, R., Prasad, G. S., Janakiraman, K. 2016. Sequence-based identification of microbial contaminants in non-parenteral products. Brazilian Journal of Pharmaceutical Sciences. 52(2): 330.

Simonova, P. M., Laukova, A., Chrastinova, L., Strompfova, V., Faix, Š., Vasilkova, Z., Ondruška, L., Jurčik, R., Rafay, J. 2009a. Enterococcus faecium CCM 7420, bacteriocin PPB CCM 7420 and their effect in the digestive tract of rabbits. Czech J. Anim. Sci. 54: 376- 386. 